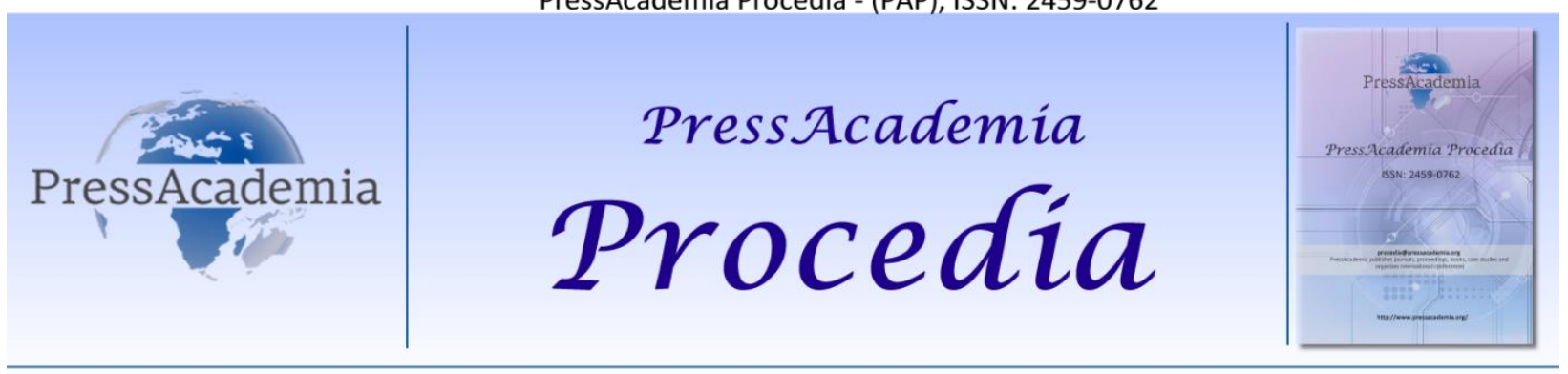

2nd World Conference on Technology, Innovation and Entrepreneurship

May 12-14, 2017, Istanbul, Turkey. Edited by Sefer Şener

\title{
ACADEMICS PERFORMANCE IN MALAYSIAN PUBLIC UNIVERSITIES
}

\author{
DOI: 10.17261/Pressacademia.2017.542 \\ PAP-WCTIE-V.4-2017(34)-p.261-264
}

Rahman Hashim ${ }^{1}$, Rahimah HP Shawkataly ${ }^{2}$

${ }^{1}$ Centre of Languages and Human Development, Universiti Teknikal Malaysia. rahmanhashim@utem.edu.my

${ }^{2}$ School of Business, Universiti Teknologi Mara, Malaysia.

\begin{abstract}
The quality of universities normally depends on their exelence and performance of academicians. Academicians normally teach efficiently besides giving full commitment to their respective institution. Academics are requested to perform better by fulfilling a series of requirements by the universities. For instance, if academics are not satisfied, they may not be committed to deliver the best. In addition, there is a possibility that their perfprmance may not achieve the target. These research aims to determine academics performance, specifically the academicians in Malaysian Public Universities, since the past few years, the rapid growth in number of universities in Malaysia has driven management to set a more ambitisious gole. Academics are requested to have a better performance by fulfilling a series of requirements such as actively involved in journal publishing. This is in-line with Malaysia quest that is to be a leading education hub in the Asia region. However, it has been established that academics remain committed to their chosen vocation and continuously demonstrate commitment to their students despite undertaking increasing workloads, administrative duties and conducting researches. The significance of this study is to contribute benefits to various parties whether the university, public universities and the State. Results from the study are expected to contribute towards the development of knowledge, especially in the feld of human resources development in order to enhance the commitment of the academic staff at public universities nationwide. The findings of this study could also assist public universities in gaming loyalty among academics who then contribute to obtaining a high-class standard of education in the Asia Pasific Region.
\end{abstract}

Keywords: Job performance, academics, commitment

JEL Codes: 037, N75, M25

\section{INTRODUCTION}

Job performance normally refers to the degree to which an individual implements his or her role with reference to certain specified standards set by the organization. In these study, the role of academics is broad and important. They are directly responsible in shaping the quality of the students. The successfulness of education always relates to the excellence and quality of the academics in the institution. The quality academics may deliver their lectures efficiently besides giving full commitment to their work place. In fact, to become the hub of a world class higher education, it is important for public universities to ensure that their academic staff perform well and has high organisational commitment. Therefore, to be able to play the role effectively, academics need to be committed to their job as educators. The satisfaction normally depends on what the employees can get or receive from the job. Besides teaching, academics are required to conduct research and publish their works. They are also expected to be involved in administration as well as clerical work which add to the workload. This may result as mood disruption, stress and dissatisfaction or discontent. To avoid or overcome this, steps must be taken to ensure that the academics are satisfied with their job. A good teaching environment and adequate equipment will prevent academicians from feeling dissatisfied with their job. Most of them believe that good ventilation in work area will improve their job satisfaction and teaching methods. If an organization is unable to provide a good working condition for their employee, employees dissatisfaction will increase and this will result in a drop in their performance. Therefore, there is strong need to understand the factors that contribute toward job performance among academics so that steps can be taken by the management to create conducive working environment that is in line with their expectation. 


\section{LITERATURE REVIEW}

In their study on The Impact of Organizational Commitment on Employees Job Performance, Negin Memari, Omid Mahdieh and Ahmad Barati Marnani (2013) discover that job performance is positively and significantly correlated with organisational commitment. Their findings also reveals that the demographic variables such as, age of the respondents both in public and private sectors has no significant variation in their job performance. The results also indicate that the males were higher performers' from female. According to Faranak Joolideh and K. Yeshodhara (2009) in their study on Organisational Commitment Amongst High School Teachers of India and Iran, they found that, Indian teachers had better organizational commitment in the affective and normative components, whereas Iranian teachers were found to have better organizational commitment in the continuance component. In both countries age groups and subject taught by teachers did not have any influence over their organizational commitment. In their study on Relationship of Work Influence, Sense of Community and Individual Spirituality towards Organizational Performance, Hazalina Mat Soha, Abdullah Osman, Sharul Nizam Salahuddin, and Safizal Abdullah (2016) determined that work influence factors are significant in influencing organizational performance in secondary school.

According to Dr Rebecca C. Tolentino (2013) in her study on Organizational Commitment and Job Performance among 248 academics and administrative staffs in an accredited university in Manila, she found that the respondents have a strong desire to remain with the university. Both the academic and administrative staff desire to stay in the university because they feel they ought to. The feeling is driven by their loyalty to the university. Academic staff has stronger affective and normative commitment than the administrative while the administrative staff have a stronger continuance commitment than the academic.

Finally, study conducted by Huam Hon Tat, Teo Pei-Ni and Amran Md Rosli (2012) found that there are three factors of job satisfaction which is job design, salary and welfare, and management. The study found that only one factor of job satisfaction which is job design has significant relationships with affective commitment.

\section{DATA AND METHODOLOGY}

These study employed a self-administered survey as a means to collecting data. A total of 300 questionnaires was distributed to respondents from the selected universities in Klang Valley and Melaka. Self-administered questionnaire form is the most common method for surveying or measuring people's interests, beliefs or perceptions (Ruziah, 2007; Aishah, 2006). The general objective of these study is to explore what are the factors that contribute toward job performance among academics in Malaysian public universities. Beside that, it also aims to determine what are the types of commitment that mostly dominant the academicians. A total of six measures were selected from established sources. These include measures of organisational commitment (Allen and Meyer, 1991; 3 measures), job satisfaction (Paul E. Spector, 1994; 1 measure), job performance (Radhakrishna, 1990; 1 measure) and religiosity (Abbas Ali, 1998 and Worthington, 2003; 1 measure). In addition, a set of 12 items of demographic characteristics is also included.

\section{FINDINGS AND DISCUSSIONS}

Out of 300 respondents, only 220 people who responded to a questionnaire that was given. The percentage of respondents who responded was $73.3 \%$. Earlier findings shows that, a total of 182 respondents were Malays ( $82 \%$ ), followed Chinese (7.3\%), Indians (4.5\%), and other races (5.5\%). The majority of respondents were aged from 30-34 years $(28.6 \%)$, then followed by $35-39$ years $(21.8 \%), 40-44$ years $(20.5 \%), 45-49$ years $(16.4 \%), 50-54(16 \%)$ and above 55 years $(16 \%)$. The result show that majority of respondents are from married person 83.6\%). In terms of length of service, majority of the academics have work for $10-15$ years (78.6\%). A total of $10.5 \%$ respondents have been working from $16-20$ years, followed by $21-30$ years $(6.4 \%)$ and more than 31 years $(4.5 \%)$. Meanwhile for the basic income, there are $20.5 \%$ with total income RM 6501 to RM 7000, 19.1\% get RM6001 to RM 6500, 11.8\% get lower RM6000, 10.9\% get RM 7001 to RM 8000 , 9.5\% get more than RM9000, 6.8\% get RM 8001 to RM 8500, and $0.5 \%$ get RM 8500 to RM 9000 .

As shown in Table 1, the relationship between organisational commitment were investigated against job performance. The reliability for job performance is 0.92. According to Sekaran (2010), reliabilities in the ranges of 0.70, is acceptable and those above 0.80 is considered as good. The results also indicates that there are significant relationship between job performance with organisational commitment $\left(r=.357^{* *}, \mathrm{p}=.000\right)$. It can be concluded that job performance is positively related to organisational commitment. The variance of the variables is $12.7 \%$. 
Table 1: Summary of Reliability Analysis

\begin{tabular}{lccl}
\hline \multicolumn{1}{c}{ Variables } & $\begin{array}{c}\text { Number of } \\
\text { Items }\end{array}$ & $\begin{array}{c}\text { Number Items } \\
\text { Discarded }\end{array}$ & $\begin{array}{c}\text { Cronbach's } \\
\text { Alpha }\end{array}$ \\
\hline $\begin{array}{l}\text { Affective Commitment } \\
\text { Continuance }\end{array}$ & 8 & 0 & .870 \\
$\begin{array}{l}\text { Commitment } \\
\text { Normative } \\
\text { Commitment }\end{array}$ & 8 & 0 & .857 \\
Job Satisfaction & 8 & 0 & .852 \\
\hline Job Performance & 14 & 0 & .889 \\
\hline Religiosity & 16 & 0 & .929 \\
\hline
\end{tabular}

Table 2: Descriptive Analysis

\begin{tabular}{lccccc}
\hline \multicolumn{1}{c}{ Variables } & $\mathbf{N}$ & Minimum & Maximum & Mean & $\begin{array}{c}\text { Standard of } \\
\text { Deviation }\end{array}$ \\
\hline $\begin{array}{l}\text { Affective } \\
\text { Commitment }\end{array}$ & 220 & 1.25 & 5.0 & 3.820 & .63300 \\
$\begin{array}{l}\text { Continuance } \\
\text { Commitment }\end{array}$ & 220 & 1.00 & 5.0 & 3.243 & .69103 \\
$\begin{array}{l}\text { Normative } \\
\text { Commitment }\end{array}$ & 220 & 1.25 & 5.0 & 3.503 & .70013 \\
\begin{tabular}{l} 
Job Performance \\
\hline
\end{tabular} & 220 & 3.00 & 5.0 & 4.1014 & .46020 \\
\hline
\end{tabular}

\section{CONCLUSION}

Base from the findings, we can conclude that the academics performance in Malaysian public universities can be considered good. Majority of them may be satisfied with the salary and benefits allocated to them. Apart from that, only a few of the academics not be happy with the management as their work may not be appreciated significantly. In addition, some of the academics are worried of what would happen if they quit their job without having another lined up. The increasing number of universities in Malaysia since the past few years, has driven management to set a more ambitious ultimate goal. Academics are requested to have a better performance by fulfilling a series of requirements, such as actively involved in journal publishing.

Implications from this study are useful for the education industry, but at the same time crucial for the society in large since the academicians are the people who educate the future leaders who will one day the pillars of the nation. Additionally, future researchers may be able to take in the limitations and recommendations into account when conducting their 
researches. Overall, this research study has provided a useful and investigable research for future studies on the performance of academicians in Malaysian public universities.

\section{ACKNOWLEDGEMENT}

These study was financially supported by Malaysian Higher Education Ministry and Universiti Teknikal Malaysia Melaka under Fundamental Research Grant Scheme (FRGS/2/2014/SS09/PBPI/02/F00247).

\section{REFERENCES}

Faranak Joolideh, K.Yeshodhara, (2009). Organizational commitment among high school teachers of India and Iran. Journal of Educational Administration, Vol. 47 Issue: 1, pp. $127-136$

Hazalina Mat Soha, Abdullah Osman, Sharul Nizam Salahuddin, and Safizal Abdullah (2016). Relationship of Work Influence, Sense of Community and Individual Spirituality Towards Organizational Performance, Procedia Economic and Finance 35 (2016) $563-573$

Huam Hon Tat, Teo Pei-Ni, Amran Md Rasli. (2012). Job Satisfaction and Organizational Commitment in a Malaysian Public University's Library. International Journal of management Sciences and Business Research. Vol. 1, Issue 6.

Munirah Salim, Halimahton Kamarudin, Mumtaz Begam Abdul Kadir. (2008). Factors affecting Organizational Commitement among lecturers in higher educational institution in Malaysia. Retrieved from www.mara.gov.my

Negin Memari, Omid Mahdieh, Ahmad Barati Marnani. (2013). The impact of organizational commitment on employees job performance. A Study of Meli Bank. Interdisciplinary Journal of Contemporary in Business, Vol. 5, No. 5

Rebecca C.Tolentino. (2013). Organizational Commitment and Job Performance of the Academic and Administrative Personnel. International Journal of Information Technology and Business Management, Vol.15, No.1

Sekaran, U., \& Boogie, R. (2010). Research methods for business: A skill building approach (5th ed.). West Sussex, UK: John Wiley \& Sons Ltd. 